Pension reform, savings behavior and capital market performance

Axel H. Börsch-Supan, F. Jens Köke and Joachim K. Winter

53-2004 


\title{
Pension reform, savings behavior and capital market performance
}

\author{
Axel H. Börsch-Supan ${ }^{*}$, F. Jens Köke*, and Joachim K. Winter* \\ * Mannheim Research Institute for the Economics of Aging (MEA), Department of Economics, \\ University of Mannheim, Germany

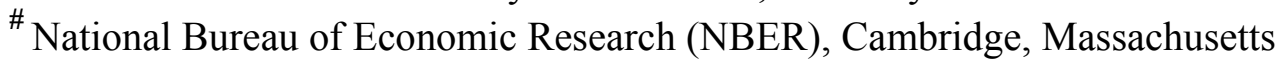

\begin{abstract}
This paper shows that the capital market effects of population aging and pension reform are particularly strong in continental European economies such as France, Germany, and Italy. Reasons are threefold: these countries have large and ailing pay-as-you-go public pension systems, relatively thin capital markets and less than benchmark capital performance. The aging process will force the younger generations in these countries to provide more retirement income through own private saving. Capital markets will therefore grow in size and active institutional investors will become more important as intermediaries. Aim of this paper is to show that these changes are likely to generate beneficial side effects in terms of improved productivity and aggregate growth.
\end{abstract}

We would like to thank Giuseppe Bertola, Julian Franks, Silke Januszewski, Kai Konrad, Jan Walliser, Alfons Weichenrieder, seminar participants at Queen's University Belfast and the Annual Meeting of the Verein für Socialpolitik and two anonymous referees for helpful comments on earlier versions of this paper that circulated under slightly different titles. Melanie Lührmann, Florian Heiss, Alexander Ludwig, and Konrad Raff provided excellent assistance. Financial support by the German Science Foundation (DFG), the Volkswagen Foundation, and the German Insurance Association (GDV) is gratefully acknowledged.

Address: Mannheim Research Institute for the Economics of Aging

University of Mannheim

D-68131 Mannheim, Germany

Fax: $\quad$ +49-621-181-1863

E-mail: Axel@Boersch-Supan.de 


\section{Introduction}

Population aging is precipitating pension reform and with it the nature of capital markets in continental Europe. It is forcing the younger generation to provide more retirement income through own private saving. The markets for retirement savings are therefore growing in size, and active institutional investors are becoming more important as intermediaries. Aim of this paper is to show that these changes are likely to generate beneficial side effects in terms of improved productivity and aggregate growth.

We start with three observations. First, France, Germany, and Italy, to take the three largest economies in continental Europe, have large pay-as-you-go (PAYG) public pension systems which face severe problems due to population aging. ${ }^{1}$ The size of the public pension systems as a percentage of GDP will increase by between 50 and 100 percent from 1995 to 2030 in France, Germany and Italy, if benefits were to remain constant in real terms (see table 1). If these additional expenditures were financed solely by contributions, the equilibrium contribution rates as a percentage of the wage bill will rise to 38 percent in France, 41 percent in Germany, and 62 percent in Italy. ${ }^{2}$ If the additional burden was financed solely by debt, it would exceed 100 percent of GDP in France, 115 percent in Germany, and as much as 180 percent in Italy by the year 2035 .

Our second observation is that France, Germany, and Italy have thin capital markets. They are thin in the sense that only few households own and control productive capital (either directly or via investment and pension funds). French, German, and Italian savers hold a considerable smaller share of stocks than households in the Netherlands, the United Kingdom, and the United States. As a result, stock market capitalization is low in these three countries, and institutional investors such as pension funds play only a minor role in household saving, see table 2 .

Third and finally, we observe that France, Germany, and Italy have, in comparison to the United States, poor capital performance as measured by aggregate capital productivity and various aggregate rates of return. While international comparisons of these statistics are not straightforward, the existing evidence summarized in table 3 yields a clear picture backed up by microeconomic evidence. Firms in France, Germany, and Italy have substantially lower capital produc-

\footnotetext{
1 OECD, 1988; World Bank, 1994; Economic Policy Committee, 2000.

2 The following projections have been computed by the International Monetary Fund (Chand and Jaeger, 1996). Similar numbers have been published by the OECD (Rosevaere, Leibfritz, Fore, and Wurzel, 1996).
} 
tivity and return on investment than U.S. companies achieve. Relative to the United States, financial underperformance is also correlated with lower levels of total factor productivity. Many authors claim that an important cause for this underperformance is weak corporate governance (see, e.g., Wenger and Kaserer, 1998; Börsch-Supan, 1998; Mueller and Yurtoglu, 2000).

The relations between these three observations are the topic of this paper. We argue that population aging and pension reform, via a change in the savings behavior and portfolio composition of households, and via strengthening capital allocation and corporate governance through active institutional investors, are likely to have important and beneficial side effects on productivity and growth that offset some of the negative macroeconomic implications of aging.

Our line of argument proceeds in two steps. First, population aging will change households' saving behavior because the internal rate of return generated by the pay-as-you-go pension systems will decrease, making own savings as a vehicle for retirement income both more necessary and attractive. In many countries, such as France, Italy, and Germany, population aging makes fundamental reform of public pension systems a top priority, strengthening own savings for retirement. Even if no additional savings were created in the aggregate, a larger share of savings will be devoted to retirement and flow through traded shares and bonds, intermediated by institutional investors. Second, the resulting larger share of intermediated capital will create thick-market externalities and has the potential to improve corporate governance. Both effects tend to increase productivity and growth. We produce microeconomic evidence based on newly assembled firm data in Germany and Great Britain which shows that actively managed investment by institutional investors enhances corporate governance and through this channel increases productivity and growth.

Research on these complex issues has not yet come far and enthusiasm for capital market related research has declined. The stock market crisis after the bubble burst and the ENRON scandal have cast grave doubts on capital market performance everywhere, including the United States. Moreover, evidence on firm performance in fundamentally different institutional settings is scarce, and establishing causality to explain observed differences is difficult. Nonetheless, capital markets will become ever more important as our populations age since capital has to substitute for increasingly scarce labor. This paper wants to pay tribute to this role. Its aim is to provide a coherent framework to study how population aging and pension reform might change capital markets, and through the capital markets growth and productivity. In order to do so, we gather 
the empirical evidence that is already available, use a macroeconomic simulation model to quantify potential effects, add new evidence on the impact of institutional investors on productivity, and highlight potential implications for public policy.

The remainder of the paper is structured accordingly. Section 2 reviews the literature. It presents various theoretical channels linking capital market features with economic performance and collects the existing evidence. Section 3 makes the first step in our argument. From a macroeconomic perspective, we compute the size of the capital stock generated by households' optimal response to population aging and under a realistic transition to a partially funded system. The potential magnitude of capital stock changes is important because it provides the leverage for changes in capital market structure and its effects on productivity and economic growth. Section 4 presents microeconometric evidence on these effects using a newly assembled panel data set of German and UK companies. Section 5 summarizes and concludes.

\section{Channels through which capital markets affect productivity and growth}

We are not the first to argue that the development of financial markets is an important factor in explaining the sources of productivity and economic growth. ${ }^{3}$ In this section, we summarize what we know about how capital markets which are thicker and funnel more funds through institutional investors affect productivity and economic growth.

Among the many theoretical models that analyze the role of financial markets for resource allocation and corporate governance, Grossman and Stiglitz (1980) and Holmstrom and Tirole (1993) show that as markets become larger and more liquid, market participants have more incentives to acquire information about firms. Jensen and Meckling (1976) and Jensen and Murphy (1990) show that linking manager compensation to stock performance helps to align the interests of managers with those of owners, and that takeovers are easier in well-developed stock markets, thus improving corporate governance.

The empirical literature that explores these mechanisms has grown dramatically over the last few years. Levine (1997) and Rajan and Zingales (2001) provide comprehensive surveys; Beck and Levine (2001) review the more recent literature. In the following, we mention only a 
few results that are of particular relevance to our argument. In a careful time-series study with aggregate data, Neusser and Kugler (1998) demonstrate that financial sector development predicts GDP growth and, in particular, total factor productivity. Levine and Zervos (1998) report that stock market liquidity is positively and robustly correlated with contemporaneous and future rates of economic growth, consistent with the view that a greater ability to trade ownership of an economy's productive technologies facilitates efficient resource allocation, physical capital formation, and faster economic growth. Levine and Zervos also find no negative impact of stock market liquidity, international capital market integration, or stock return volatility on private savings. Similar findings have been obtained by Rajan and Zingales (1998) who compare industrial sectors across countries, arguing that financial development reduces the costs of external finance to firms. Wurgler (2000) confirms that financial markets play an important role in the capital allocation process. He reports that the efficiency of capital allocation is positively correlated with the degree of legal protection of investors (i.e., in Anglo-American, market-based financial systems). In particular, Wurgler argues that market-based systems are more successful in limiting overinvestment in declining industries. Using cross-country panel data, Beck, Levine, and Loayza (2000) and Levine, Loayza, and Beck (2000) show that financial intermediaries exert a large, positive impact on total factor productivity and GDP growth. Finally, Beck and Levine (2002) argue that while legal system efficiency and overall financial development boost economic growth, there appears to be no significant difference between market or bank-based financial systems.

One frequently made objection against a causal interpretation of the relation between financial markets development and economic growth is that financial development is only a leading indicator of growth, i.e., that expected of economic growth causes improvements in the financial sector. It is our reading of the literature that the well-documented positive effect of financial market development on economic growth is not due to reversed causality. The study by Beck and Levine (2001) confirms this view. They use sophisticated econometric panel methods with data from 40 countries and the 1976-1998 period. With these more robust econometric techniques, they maintain the result that both stock markets and banks have a positive effect on economic

\footnotetext{
3 See Levine (1997) for an extensive review of this literature and Carlin and Mayer (2003) for a more recent contribution.
} 
growth and that this result is not due to simultaneity, reverse causality, or unobserved countryspecific effects.

In order to break the potential simultaneity, some recent studies employ data at a more disaggregate level than the macroeconomic analyses mentioned above. There are two avenues. First, there is a large number of case studies which investigate the effect of active pension funds in those countries where they exist. We will summarize them in the sequel of this section. The second avenue employs industry- and company level data that provide direct evidence on the existence of a causal channel from financial market development, and in particular corporate governance, to productivity growth. Such data is scarce. McKinsey (1996) and Börsch-Supan (1998) use proprietary company data. Köke and Renneboog (2002) is another example of a microeconometric study that links corporate governance and productivity using a generally accessible firm panel. In section 4 of this paper, we follow their approach.

An important way for pension fund managers to improve the performance of their funds is to take an active role in improving corporate governance. The role of large shareholders in disciplining management and the effectiveness of shareholder activism are central to understanding the macroeconomic consequences of an increase in pre-funded pensions. ${ }^{4}$ The basic theoretical argument has been made, for example, by Pound (1988): Institutional investors such as pension funds that have no business relations with a firm can do a better job in disciplining management. To further our main argument, it would be most helpful to substantiate Pound's (1988) theoretical analysis with data on French, German, and Italian pension funds. Pension funds, however, and mutual funds more generally, play almost no role in corporate governance in most continental European countries. As reported by the Bank for International Settlements (1998), in 1996 pension fund assets represented only 3 percent of total GDP in Germany and 4 percent in Italy, while in the U.S. and the U.K., the shares are 57 percent and 77 percent, respectively (see table 2). Götzfried (1999) presents a more detailed analysis of the role of pension funds in major European countries. His results are based on a survey conducted by Eurostat in 1997. As might be expected, the number of independent pension funds is high in those countries that rely heavily on funded pension schemes, i.e., the Netherlands and Switzerland (there are no comparable data for

\footnotetext{
4 The impact of pension reform on financial markets has also been analyzed, with slightly different objectives, by Blommestein (2001), Scatigna (2001), and Davis (2002).
} 
the U.K.). In contrast, the number of independent pension funds in Germany is extremely small. At the same time, Germany has the largest number of firm-specific pension plans among those European countries covered, but in terms of their investment behavior, these are very different from pension funds in the narrow sense of the word.

There are several reasons for these differences in the economic role of pension funds. First, and most importantly, the majority of pension income is provided by the public PAYG pension system, as has been described in section 3. Thus, few households invest in pension funds in the first place. Second, mainly due to tax advantages, individual retirement saving has traditionally been channeled mainly into whole life insurance. Life insurance companies are legally barred from investing more than a small part of their portfolios in stocks - up to about 30 percent of assets for traditional whole life insurance according to life insurance regulations, but much less in practice. ${ }^{5}$ Third, typical for Germany, less so for France and Italy, assets that are accumulated for funded firm pension schemes are often not invested in the capital market, but are set aside as capital reserves in firms' balance sheets, again because of legal and tax reasons. As a result of these institutional arrangements, France, Germany, and Italy have few institutional investors and stock market capitalization is low by international standards (see table 2 above).

Given the small role that pensions have historically had in the three large continental European countries with dominant PAYG pension systems, we cannot provide empirical evidence based on past experience. Rather, we discuss how pension funds influence corporate governance in those countries in which they already play a major role. These countries provide a large number of studies which evaluate the effectiveness of pension fund activism. Black (1998) surveys the literature on large shareholder and pension fund activism and concludes that pension fund interventions are generally ineffective. However, there are also quite a few studies which indicate that pension fund activism has beneficial effects and that agency problems are not a major concern in practice. For example, Del Guercio and Hawkins (1999) study shareholder proposals of the largest, most active funds from 1987 through 1993. They conclude that pension funds are successful at monitoring and promoting change in target firms, and they do not find evidence

5 In Germany, insurance companies have recently started to offer other life-insurance products which allow heavy investment in risky assets such as stocks in recent years, but until now, they claim only a small share of the market. 
to support that funds have other motivations than value maximization. This result can be interpreted as indicating that agency problems might not be a major concern in practice.

Several empirical studies concentrate on the best-known example of an active pension fund, the California Public Employees' Retirement System (CalPERS), the largest public pension fund in the U.S. and third largest in the world with total assets over 164 billion US Dollar in 1999. Over the last decade, CalPERS has been at the forefront of shareholder activism, with an explicit goal "to efficiently and effectively manage investments to achieve the highest possible return at an acceptable level of risk." To this end, CalPERS reviews the performance of the U.S. companies in its stock portfolio on a regular basis and identifies those that are among the lowest long-term relative performers. This review process results in a list of companies that are publicly identified as a "CalPERS focus company". In 1999, this list covered nine companies. Among other interventions, CalPERS filed 65 shareholder's proposals in order to improve firm performance of its focus companies during the 1987-1998 period. The average annual rate of return was $13.2 \%$ over these ten years. ${ }^{6}$ Nesbitt (1994) reports weak evidence that CalPERS interventions affected stock prices of targeted firms positively. Smith (1996) analyzes 51 firms out of the 78 targeting events of CalPERS over the 1987-93 period. He finds that shareholder wealth increases for firms that adopt or settle, and decreases for firms that resist changes proposed by CalPERS. Smith concludes that "shareholder activism is largely successful in changing governance structure, and, when successful, results in a statistically significant increase in shareholder value" (p. 251).

Based on these theoretical and empirical findings about the link between active pension funds and firm performance, we expect that an increase in the volume of equity and corporate bonds controlled by institutional investors would have noticeable effects on corporate governance in continental European countries, and thus provide positive effects on aggregate productivity. We are, however, aware of counterexamples. While we have seen that pension funds have helped to improve corporate governance and productivity in many instances, there are also cases in which investment funds did not perform so well. A prominent example is the case of the provident funds in Southeast-Asia which have destroyed wealth, as detailed by Asher (1998). While

\footnotetext{
6 These figures and statements are taken from CalPERS' internet site (http://www.calpers-governance.org). This site contains detailed information on CalPERS' investment strategy and its position on corporate governance and shareholder activism.
} 
they contributed to economic growth through a massive accumulation of capital, they did not increase total factor productivity; see also Kim and Lau (1994) and Young (1994). These two faces of the Asian miracle were of dramatic relevance in the recent Asian crisis, and they bear several lessons for funded pension systems. In particular, the Asian experience shows the importance of competition among institutional investors as realized in the Anglo-Saxon countries and, to a lesser extent, in the Netherlands and Switzerland.

As stated in the introduction, this paper is mainly concerned with the large continental European countries, notably France, Germany, and Italy, which, as we will argue in the following section, will build up significant retirement saving during the next decades, mainly channeled through institutional investors. Section 4 will then investigate the potential effects of these capital market changes on economic performance.

\section{Capital market implications of population aging and pension reform}

Population aging puts tremendous pressures on the contribution-based PAYG pension systems which dominate retirement income in continental Europe. Prime examples are France, Germany, and Italy whose monolithic public pension systems cover almost all workers and provide most of their retirement incomes. ${ }^{7}$ While a full transition to pre-funding is both unrealistic and undesirable, the scientific debate has converged to a consensus view that a funded component needs to be introduced in order to complement the existing PAYG systems; see, among others, Miles and Timmermann (1999), Boldrin, Dolado, Jimeno, and Peracchi (1999), Disney (2000), Sinn (2000), and Börsch-Supan (2002). Pension reforms that entail a significant extent of pre-funding have also become politically more attractive (Boeri, Börsch-Supan, and Tabellini, 2001, 2002). In fact, Italy has started in the mid 1990s to implement a mixed multi-pillar systems for new entrants, Germany has acted later but introduced a much faster transition in 2001 and 2004, and it appears that France will follow suit, albeit at slow speed. With a larger share of prefunded pensions, capital markets and their governance mechanisms will play an increasingly important role in the future. 
The main task of this section is to show how large this role will be under realistic assumptions, using a multi-country OLG model that allows for quantitative projections of the savings generated under population aging and pension reform. This model is an important first step in our chain of arguments: it shows the quantitative importance of the shifts in the demand and supply of capital that will be induced by population aging and pension reform. The task is difficult because there are several countervailing forces at work. Population aging changes the balance between capital and labor. Labor supply is going to be relatively scarce in the aging countries, whereas capital is going to be relatively abundant. This will drive up wages relative to the rate of return on capital, reducing households' incentive to save (if the interest elasticity of saving is positive). In addition, some fraction of the capital stock may become obsolete due to the shrinking labor force and diminishing returns to scale, making the accumulation of capital even less attractive. ${ }^{8}$

The picture gets more complicated when three additional aspects are taken into account. First, in the shorter term, the behavior of the savings rate is quite different since the strong baby boom cohorts reach the most savings-active stage of the life cycle. Second, a domestic view does not do justice to the global nature of capital markets. Capital exports from fast-aging countries to those countries with a more favorable age structure will reduce the aging-related decline of savings (Blommestein, 1998; Reisen, 2000). ${ }^{9}$ Third, pension reform towards a higher degree of prefunding will create higher saving rates unless it is fully crowded out by a decline in nonretirement related savings.

In order to quantify these countervailing effects, we apply the dynamic simulation model developed by Börsch-Supan, Ludwig, and Winter (2004). This model is a multi-country, 85generation, endogenous labor supply version of the overlapping generations (OLG) model introduced by Auerbach and Kotlikoff (1987). For our present purposes, this model is well suited because of three features. First, we use very detailed demographic projections based on United Nations (2002), permitting the study of short- as well as long-term developments. Second, we care-

7 For a detailed description of the French pension system see Blanchet (1999), for the German system see Börsch-Supan and Schnabel (1999), and for the Italian system see Brugiavini (1999). The Netherlands, Switzerland, and the United Kingdom are notable exceptions from these all-encompassing pay-as-you-go systems.

8 Loayza, Schmidt-Hebbel, and Servén (2000) present empirical evidence for the negative long-run effect of increasing old-age dependency ratios on saving. 
fully model the PAYG pension system enabling us to study the effects of pension reform on the aggregate saving rate, including potential crowding out. Third, we model a multi-country setting where countries exhibit different aging processes, allowing for endogenous aging-induced capital mobility.

Figures 1 through 3 present the results. We focus on the region defined by the three large Continental European countries, France, Germany and Italy. Figure 1 is our baseline projection of the effect of population aging on the aggregate household saving rate. This effect depends on the international diversification possibilities, represented by three capital mobility scenarios. We first model the three large Continental European countries as a single closed economy. We then simulate a two-region world consisting of the three countries as one region and the other OECD countries as the other region with free capital mobility between the two regions. Third, we show a three-region model with the rest of the world as a third region under global free capital mobility.

Figures 2 and 3 display the additional effects of a prototypical pension reform. In the baseline scenario, the existing PAYG systems in the three countries are maintained at the 2006 replacement rates. The pension reform scenario is based on a stylized pension reform which induces a substantial extent of pre-funding by freezing the 2006 contribution rates of the PAYG pillars. A funded pillar is implicitly introduced by freezing the PAYG contribution rate and reducing PAYG benefits accordingly. This induces the rational life-cycle planning households in our OLG model to increase private saving, leading eventually to a mix in which about one third of retirement income comes from private saving and two thirds from the PAYG system.

Figure 1 shows that population aging results in a substantial drop of the aggregate saving rates in France, Germany and Italy under the current PAYG system. The aggregate saving rate decreases from 2000 until about 2050 across all capital mobility scenarios since the baby boom generation decumulates assets. In the existing pension systems scenario, the decrease of the savings rate caused by population aging - the difference between the value in 2000 and the minimum reached in about 2050 - is roughly 5 percentage points in the three-country closed-

9 There is some empirical evidence that the mechanism of age-induced capital flows is already at work (e.g., Higgins, 1998; Lührmann, 2003). 
economy scenario and about 6.5 to 7.5 percentage points if we allow for capital mobility within the OECD and the entire world, respectively.

Figure 2 shows the differential effect of a stylized pension reform that freezes PAYG contribution rates after 2006 and therefore increases the role of private retirement provision. Projected aggregate saving rates under a fundamental pension reform are substantially higher than without pension reform, in particular in the open-economy scenarios (about 2 percentage points). Hence, optimal life-cycle behavior generates additional saving under a fundamental pension reform, even though some crowding out takes place. Our projections indicate a substitution of about one third, leaving two thirds to new saving.

Finally, figure 3 shows the leverage of newly created retirement saving on the capital market. It displays the amounts seen in figure 2 as share of total saving. Even in the closed economy scenarios, this share reaches 30 percent at the peak of the aging process. More retirement saving is generated when international capital markets permit higher returns in those countries which age less than France, Germany and Italy. This leads to retirement saving shares in excess of 50 percent of total saving around the year 2050, creating a substantial leverage for potential productivity effects. ${ }^{10}$

Are these projections credible? Their crucial ingredient is the consumption smoothing life-cycle saving mechanisms employed in the OLG model. Is this backed by the microeconometric evidence? Figure 4 shows, by age group, median saving rates in France, Germany, Italy and the Netherlands. They are based on a comparable longitudinal framework, represent life-cycle saving purged from cohort effects, and employ comparable variable definitions and data sources as part of the International Saving Comparisons Project (Börsch-Supan, 2001). The saving profiles in France, Germany, and Italy are rather flat and show no dissaving in old age, in contrast to the strong hump shape generated by the simple life-cycle saving mechanism. Does this invalidate the projections of figures 1 through 3 ?

We do not think so. A tempting explanation of the flat life-cycle saving profiles is that the high replacement rates of the public pension systems in these countries have made private retire-

\footnotetext{
10 The shares in figure 3 are an underestimate since they do not include those new retirement savings that have crowded out other
} saving (about one third in the closed economy case). 
ment income largely unnecessary. ${ }^{11}$ If other saving motives, such as precaution and intergenerational transfers, are more important than retirement saving, age-saving profiles are likely to be much flatter than under the textbook life-cycle hypotheses which predicts saving in young and dissaving in old age. This explanation is in line with the work by Jappelli and Modigliani (1998) who argue that the main mechanism for "retirement saving" in Italy is the PAYG system. While we lack the most appropriate counterfactual to substantiate this explanation - French, German, and Italian data from times when these countries had no PAYG systems - figure 4 depicts the case of the Netherlands which have, as opposed to France, Germany, and Italy, only a small base pension provided by their PAYG public pension system. All additional retirement income in the Netherlands has to be provided by (mandatory) savings plans, commonly provided through occupational pension plans. Figure 4 shows that the median Dutch household has a much more pronounced hump-shaped life-cycle savings profile than the median French, German, and Italian households, and it exhibits dissaving among the elderly as they draw down their mandatory saving accounts.

This cross-national microeconomic evidence therefore suggests that the consumptionsmoothing mechanism employed in the OLG model may be a quite appropriate prediction device. A pension reform towards a multi-pillar system with a substantial portion of funded retirement income will revive the retirement motive for saving in France, Germany, and Italy. In fact, these systems will look very similar to the current Dutch system. Hence, it is likely that saving rates among the young will increase (to accumulate retirement savings), and saving rates among the elderly will decline sharply (because they will dissolve their retirement savings), just as in our OLG model. Combining the results of figures 1 and 4 gives us an order of magnitude for those effects. The net saving rate of the average German household in mid age would increase by about 4 percentage points from 11 to 15 percent, while the saving rate would decrease by about 6 percentage points from 4 to -2 percent in old age, when retirement accounts are drawn down for consumption. Portfolio composition is likely to change under such a shift. The increase in saving by the middle-aged predicted above amounts to between 15 and 18 percent of those households' portfolios, quite close to the actual shares currently observed in the United Kingdom, the U.S.,

11 See Boeri, Börsch-Supan and Tabellini (2001) for a comparison of replacement rates. 
the Netherlands and Switzerland. These additional retirement savings are the basis for the potential productivity effects to which we now turn.

\section{Institutional investors and firm performance in Germany and the UK}

Ultimately, higher productivity must be generated at the firm level. In this section, we therefore investigate the impact of the various mechanisms discussed in the previous section - in particular, the role of institutional investors as growing players on the capital markets - on firmlevel productivity growth using newly assembled firm-level data in Germany and the UK. The core idea of this section is to parametrize total factor productivity by the key factors that were identified in section 2 as main channels through which capital markets affect productivity, notably variables which describe financial market conditions and the stringency of corporate governance, plus possibly confounding factors.

The analysis in this section is driven by three working hypotheses:

- Hypothesis 1: Tight owner control increases productivity growth.

- Hypothesis 2: Tight creditor control increases productivity growth.

- Hypothesis 3: Monitoring by traditional financial institutions (such as banks and insurance companies) and non-financial firms should be more important for Germany, whereas monitoring by advanced financial institutions (such as mutual funds and pension funds) should be more important for the UK. Their impact on productivity growth might differ.

The first hypothesis follows Shleifer and Vishny (1986) who argue that a large share block provides the owner with an incentive to collect information and to monitor management. A large blockholder also has enough voting power to put pressure on management. In contrast, in firms with a dispersed shareholder structure free-riding behavior should make monitoring too costly (Grossman and Hart, 1980). Hence, we expect closer monitoring for firms under control of a strong owner, and that this is reflected in higher productivity growth.

The second hypothesis recognizes that also creditors and bondholders may perform a disciplinary function. Jensen (1986) argues that debt financing reduces free cash flow and therefore has a disciplinary effect on management. Management can use high leverage to signal credibly that they maximize profits. We expect that any disciplinary impact that creditors have on man- 
agement should be the greatest when a large fraction of debt is bank debt. Likewise, pressure from bondholders should be the greatest when a large fraction of current earnings must be used to pay interest on debt obligations, i.e., when interest coverage is low.

The corporate governance systems of Germany and the UK feature some fundamental differences. Germany is often described as having a bank-based governance system because German banks possess a variety of control rights through direct share ownership, voting power based on proxy votes, long-term lending relationships to borrowers, and supervisory board membership (Edwards and Fischer, 1994). In contrast, the UK is often described as having a market-based governance system because capital markets are deep, institutional ownership of stock is high (e.g., through mutual funds and pension funds), and takeovers occur regularly. The third hypothesis states that these differences in the institutional setting and the capital market environment support particular governance mechanisms in Germany (such as monitoring by banks and insurance companies) and others in the UK (such as monitoring by mutual and pension funds). Theoretical arguments support the notion that the quality of monitoring depends on the type of shareholder. Hence, we investigate Germany and the UK separately and employ country-specific measures for ownership and capital structure.

In addition, the impact of ownership and capital structure may depend on the environment a firm is operating in. More specifically, we expect that shareholders and creditors/bondholder increase governance action when a firm runs into financial difficulties. The reason is that poor financial performance may serve as a signal of poor management quality. Similarly, intense product market competition may strengthen corporate governance action by shareholders and creditors/bondholders when managers' performance becomes clearly observable. ${ }^{12}$ To capture these potential effects, a set of control variables needs to be included in our empirical analysis.

\subsection{The model}

Starting point of our analysis is a conventional production function which relates output to capital, labor and total factor productivity (TFP):

12 In turn, intense competition may also make corporate governance action less necessary when competition alone is sufficient to assure good management. 


$$
y_{i t}=\lambda y_{i t-1}+(1-\lambda) \beta_{L} l_{i t}+(1-\lambda) \beta_{K} k_{i t}+(1-\lambda) a_{i t}+\alpha_{i}+\mu_{t}+\varepsilon_{i t}
$$

where $y_{i t}$ denotes output, $k_{i t}$ capital, $l_{i t}$ labor and $a_{i t}$ TFP of firm $i$ in year $t$, all expressed in logs. Time effects $\mu_{t}$ filter out aggregate productivity shocks. Heterogeneity and state dependence are captured by the fixed firm effect $\alpha_{i}$ and by lagged output $y_{i t-1}$, weighted by $\lambda$, respectively. We eliminate the fixed firm effects by taking first differences of equation (1) and parametrize productivity growth with our variables of core interest:

$$
\Delta a_{i t}=\beta_{1} \cdot \text { CAPITALSTRUCTURE }_{i t}+\beta_{2} \cdot \text { OWNERSHIPSTUCTURE } i t+\beta_{3} \cdot \text { CONTROLVARIABLES }_{i t}
$$

\subsection{The data}

We use firm-level data from Germany and the UK. For Germany, the sample covers the years 1986-1996 and contains data from 1074 firms (6476 firm years). These firms are large corporations which are listed or not listed on a German stock exchange. The sample covers approximately $63 \%$ of all large public corporations (Aktiengesellschaft) and is therefore representative for this type of firm. ${ }^{13}$ Coverage of private corporations $(\mathrm{GmbH})$ is much thinner and concentrates on larger firms. Most firms belong to the manufacturing sector ( 841 firms), a smaller number to the construction industry (57 firms) and wholesale and retail trade (176 firms). Balance sheet data are taken from Hoppenstedt's Bilanzdatenbank, which is commercially available. Information on ownership structure is collected from various editions of Hypobank's Aktienführer as well as Hoppenstedt's Konzernstrukturdatenbank. A detailed description of these data sources can be found in Köke (2002a).

For the UK, our sample covers the years 1992-1999 and contains data from 502 firms, all of which are listed on the London Stock Exchange. The sample consists of more than one third of all non-financial listed firms and captures over $85 \%$ of market capitalization. The largest number of firms belongs to the manufacturing sector (314 firms), a smaller number to the construction industry (35 firms), and wholesale and retail trade (153 firms). Balance sheet data are taken from

\footnotetext{
13 The sample excludes all firms from the financial services industries as well as firms that operate in industries still heavily regulated during the period of observation (e.g., media, telecommunication, and transport).
} 
Thomson Financial Datastream, which is commercially available. Information on ownership structure is collected from Worldscope Disclosure archives. To make the distinction between the more than 5000 insider and outsider individual shareholders, we consulted the London Stock Exchange Monitor and the "Who's Who" guides. To identify institutional shareholders, we consulted Datastream, Institutional Investors Annual Guides and the world wide web.

To measure corporate governance, we use data on ownership structure and capital structure. The main variable to measure ownership is an indicator whether a firm is under control of a large blockholder or not $(C O N T R O L)$. For the UK, this variable indicates the presence of a shareholder who owns at least $10 \%$ of all outstanding shares. This definition takes into account that ownership in the UK is relatively dispersed and a block of $10 \%$ already represents a large block. For Germany, ownership concentration is much higher than in the UK, and German corporations are often owned through pyramid structures and cross-shareholdings (Becht and Röell, 1999). These two characteristics imply that concentration measured at the direct level of ownership can be misleading for German firms (Becht and Böhmer, 2003; Köke, 2002b). Therefore, for Germany CONTROL indicates whether a firm is under control of awell-defined ultimate owner (rather than under dispersed ownership or held by two or more blocks of about equal size). The concept of ultimate ownership, described in detail by Köke (2002b), allows for complex control structures and high ownership concentration. Applying these measures to our sample, see table 4, we find that $89.6 \%$ of German firms have an ultimately controlling shareholder, and $83.0 \%$ of UK firms have a shareholder who owns at least $10 \%$ of all outstanding shares.

We also identify the type of the controlling shareholder for each firm (TYPE). In our sample, the largest fraction of German firms is ultimately owned by a non-financial firm $(41.4 \%)$ or a private owner (35.6\%), see table 4 . Only $5.4 \%$ of sample firms are ultimately owned by a bank, and $2.3 \%$ are controlled by other financial institutions. For the UK, the distribution of shareholders is strikingly different. The largest fraction of firms is controlled by a financial firm $(45.3 \%)$. Among these, mutual and pension funds are the dominant category (39.2\%). The position of private owners (29.4\%) is comparable to Germany.

Regarding capital structure, we use different measures for Germany and the UK. For Germany, our preferred measure is the ratio of bank debt to total debt $(B A N K)$. We expect this measure to be a good proxy for the power of banks in bank-based Germany. For the UK, the role of banks is not as prominent as in Germany. In the market-based UK system, all types of bondhold- 
ers may play a governance role. Therefore, our preferred measure is the borrowing ratio $(B O R R O W)$, which is measured as interest payments over earnings before interest, taxes, and depreciation. In the present sample, the ratio of bank debt to total debt amounts to $26.1 \%$ on average for Germany. For the UK, we find an average borrowing ratio of $15.1 \%$ (see table 4).

To measure the intensity of product market competition, we determine firm's rents from production (RENT) which can be interpreted as an ex post measure of market power. It serves as an inverse measure of competition. The motivation for using this measure is that firms operating in less competitive markets should be able to sell their products well above marginal cost, and therefore earn higher rents after covering their expenses (on capital, labor, and materials); see Nickell, Nicolitsas, and Dryden (1997) and Januszewski, Köke, and Winter (2002) for earlier empirical implementations of these competition measures.

\subsection{Estimation results and interpretation}

Our empirical model of productivity growth is given by equations (1) and (2). The structure of this model corresponds to the differenced panel model with lagged endogenous variables considered by Arellano and Bond (1991). We employ their generalized method of moments (GMM) estimator that allows to exploit lags of the lagged dependent variable as well as lags of the explanatory variables as instruments. Using this approach addresses the potential endogeneity problems with respect to the corporate governance and competition variables. ${ }^{14}$

In a first step, we relate debtholder influence (measured as $B A N K$ for Germany and BORROW for the UK) and shareholder influence (measured as CONTROL) to productivity growth; see model 1 in table 5. For Germany, we find that a higher fraction of bank debt to total debt is associated with higher productivity growth. Interpreting bank debt as a measure of creditor influence, these findings suggest that firms experience higher productivity growth when being under tight creditor control. Note that only about one quarter of German firms are under such

\footnotetext{
14 Arellano and Bond (1991) show that endogenous variables lagged two or more periods are valid instruments, provided there is no serial correlation in the time-varying component of the error terms in equation (2); we test this condition for all specifications. The instruments we use are $y_{i t-j}$ for $j \geq 2$, and second lags of RENT and ASSET. We test for instrument validity using a Sargan test of over-identifying restrictions. We report those tests together with the estimation results and standard errors that are robust with respect to general heteroskedasticity in the next section. Following Arellano and Bond (1991), we use the two-step version of the GMM estimator for obtaining the Sargan test statistic, while coefficient estimates are based on the one-step version. Arellano and Bond report that the one-step Sargan test is sensitive to heteroskedasticity, tending to over-reject the null.
} 
tight control (see table 4). For the UK, none of these measures has an impact on productivity growth.

In a second step, we investigate the interaction between competition (measured as RENT), poor performance (measured as LOSS) and corporate governance; see model 2 in table 5. For Germany, we find evidence that the disciplinary impact of high bank debt on productivity growth is strenghtened by poor financial performance. This suggests that creditors improve corporate governance particularly when firms are in financial difficulties, i.e., when they are dependent on bank credit. The interaction of rent and bank debt is weakly significant and positive, indicating that intense competition and creditor influence are substitutes. Regarding shareholder influence, the presence of a strong owner has a beneficial impact on productivity growth. The interaction of rents and shareholder influence is significantly negative, indicating that intense competition and shareholder influence are complements. For the UK, we find a negative coefficient of CONTROL, our indicator variable for tight owner control, and positive interaction terms with RENT and LOSS. These results suggest that the presence of a large shareholder has a negative impact on productivity growth, and intense competition in product markets cannot compensate for this effect. Only when financial performance is poor, i.e., when the respective firm makes earnings losses, tight owner control has a beneficial impact on productivity growth and may overcompensate for the negative impact of shareholder control. Competition by itself has a weakly beneficial impact on productivity growth.

In a third step, we make use of detailed information regarding the type of shareholders. More specifically, we identify the type of the ultimate owner (for Germany) and the type of the largest shareholder that owns more than $10 \%$ of outstanding shares (for the UK). These types of owners, detailed in table 4, enter the regression model instead of CONTROL and are interacted with RENT and LOSS, see model 3 in table $6 .{ }^{15}$ For Germany, bank debt keeps its beneficial impact on productivity growth for firms in financial difficulties. Likewise, firms under tight owner control show significantly higher productivity growth, but only when the ultimate owner is a bank or an insurance company. This is an important result: Companies under the control of institutional investors have higher productivity - but less than $8 \%$ of German firms are under such control ( $5.4 \%$ are ultimately owned by banks, $2.3 \%$ by insurance companies, see table 4 ). 
This beneficial impact of shareholder control is reinforced by intense product market competition, as the negative coefficient of the interaction between TYPE and RENT indicates. There is also weak evidence that firms under government control show higher productivity growth; again this effect becomes stronger when at the same time competition is intense. For the UK, the intensity of competition keeps its positive impact on productivity growth. The analysis of different types of shareholders reveals where the negative impact of a strong owner comes from: it is mainly the influence of insiders, i.e., executive and non-executive directors, that reduces productivity growth. This negative impact is not compensated by intense competition in the product markets. Taking the sum of the coefficients for $R E N T, T Y P E_{j}$, and the interaction of both variables gives the impact of RENT for firms under control of shareholder category $j$. A Wald test shows that this impact is positive for private insider and zero for banks. For all other types of shareholders, this joint impact of RENT and TYPE is zero. Generally, intense competition does not appear to have a beneficial impact on productivity growth for firms under strong ownership. Vice versa, these findings imply that competition plays a disciplinary role for firms under dispersed ownership. Finally, the interaction of TYPE with the indicator for earnings losses (LOSS) shows that private shareholders, banks, and funds have a beneficial impact on productivity growth for firms in financial difficulties. All versions of our GMM model are supported by the standard battery of specification tests. In particular, the Sargan tests do not reject the hypothesis of instrument validity. We also test the sensitivity of our results with respect to alternative definitions of key explanatory variables and find that none of our key results is sensitive to these sensitivity checks.

In summary, therefore, our findings suggest that financial institutions do indeed fulfill a monitoring function. In Germany, institutional investors - banks and insurance companies - have a beneficial impact on productivity growth. German banks also play a disciplinary role as creditors because they enhance productivity growth of poorly performing borrowers. These results stand at odds with a skeptical view on the German model of corporate governance. It is often argued that corporate governance in Germany is too bank-oriented and therefore too inflexible compared with the Anglo-Saxon market-oriented system. While we do not explicitly test for the impact of 'housebank' relations, our results suggest that lending relationships and institutional

\footnotetext{
15 The owner category 'dispersed' acts as the reference category.
} 
ownership in Germany cannot simply be dismissed as too inflexible and outdated, as often argued. Our results are therefore consistent with Cable (1985), who documents a disciplinary role of German banks for the 1970's, and with Elsas and Krahnen (1998), who confirm (based on credit-file data) that German housebanks provide liquidity insurance in times of financial difficulties. ${ }^{16}$ Renneboog (2000) provides a similarly positive assessment of Belgian banks. The important point here, however, is that this beneficial impact on tight control through institutional investors is rarely realized because most firms are under less tight control. Only $7.7 \%$ of German firms are ultimately owned by institutional investors.

For the UK, we do not find evidence that creditors or bondholders have a beneficial impact on productivity growth. Whereas past research on the monitoring ability of institutions (Franks, Mayer, and Renneboog, 2001) and on the role of occupational pension funds (Faccio and Lasfer, 2000) doubts that institutions contribute to good corporate governance, we find that the presence of financial institutions as shareholders (in particular, mutual and pension funds) stimulates productivity. Especially when firms are in financial difficulties and funds own a large fraction of outstanding shares, total factor productivity grows faster than in other firms. The beneficial impact on firm performance of these sophisticated institutional investors is consistent with evidence from the US (Carleton, Nelson, and Weisbach, 1998; del Guercio and Hawkins, 1999), although the absence of a beneficial impact of other types of large shareholders as well as creditors also stands in contrast with Nickell, Nicolitsas, and Dryden (1997) and Nickell and Nicolitsas (1999), who report that creditors and non-financial companies as shareholders tend to influence productivity growth positively.

\section{Summary and policy conclusions}

We have shown that population aging will change saving behavior, and that pension reform - an ongoing process in the core European countries - will amplify these changes. Popula-

\footnotetext{
16 Our results are also consistent with Gorton and Schmid (2000) and Lehmann and Weigand (2000) who find a positive impact of bank ownership on earnings-based performance measures. However, they are inconsistent with Edwards and Nibler (2000), who do not find evidence that German banks are different from other large corporate shareholders, and Januszewski et al. (2002), who report a negative impact of financial institutions on productivity growth. While similar in methodology, the latter study had to neglect the role of capital structure, its interaction with competition, and the impact of poor financial performance, because appropriate data were not yet available.
} 
tion aging will induce an increase in savings between 2015 and 2025. Saving rates will decline thereafter. Pension reform adds to the increase and dampens the decrease even though about one third of saving for retirement will displace other saving. A higher than current share of saving will then flow through stock and bond markets, thereby changing the nature of the capital markets in those countries in which stock market capitalization is low and industrial bonds are rare notably in the three large Continental European countries France, Germany, and Italy. Moreover, this paper has assembled evidence that the size of capital markets and productivity growth are related, and that larger capital markets and actively managed investment and pension funds enhance corporate governance. Hence, there are beneficial side effects through capital markets which will dampen the negative effects of population aging.

Our argument also adds a new and important dimension to the continuing debate of advantages and disadvantages of PAYG and fully funded pension systems. While we know that in steady state, funded pension systems are advantageous relative to PAYG pension systems whenever the interest rate exceeds the growth rate of the wage bill, we also know that this is of little help in the case of an economy which already has a PAYG pension system, as stressed by Sinn (2000). Such an economy has to pay back its implicit debt which had financed pension payments to the first generation of beneficiaries, before being able to enjoy the advantages of a funded system. Paying back this implicit debt implies a consumption loss - the so-called transition burden. In a simple Solow economy with a fixed technology, the consumption loss due to the transition burden is exactly equal to the consumption gain that will be achieved through the higher capital stock in a funded pension system (Aaron, 1966). The result also holds under more general conditions, e.g., when pension benefits must be financed by distorting payroll taxes that are in proportion to pension benefits (Brunner, 1996; Fenge, 1997).

This equivalence result, however, rests on a crucial condition, namely fixed household behavior (i.e., saving rates and portfolio choice) and a fixed technology (i.e., factor productivities). We have argued in this paper that these assumptions are counterfactual. Rather, we are likely to experience changing saving rates and portfolio choices, and we will see major shifts in the allocation of capital, inducing changes in efficiency in those countries that have thin capital markets, such as France, Germany, and Italy. This opens the possibility for efficiency and welfare gains of a partial transition from a PAYG to a funded pension system, which reduce and even might outweigh the transition burden. 
Is this possibility a real one? Aren't these capital market effects quantitatively irrelevant second order effects? We believe not. In order to assess the magnitude of the potential feedback effects that must be induced by improvements in capital allocation in order to compensate for the transition burden, consider again our example of a fundamental pension reform in Continental Europe that would imply a partial transition towards a one-third funded pension system. We again use the macroeconomic simulation model developed by Börsch-Supan, Ludwig, and Winter (2004) to quantify these effects. Figure 5 shows the utility loss implied by the transition burden of the pension reform. Without positive efficiency effects, some generations would be net losers. Figure 5 also shows the utility gains and losses for various increases in total factor productivity. Already a relatively small transient productivity effect of just 0.2 percentage points per year makes all generations better off.

This is an important result. It must be appreciated together with the political economy arguments made by Boeri, Boersch-Supan, and Tabellini (2001, 2002). They found that people in France, Germany, and Italy are well aware that population aging will put their pension systems into crisis. A majority also agrees to a fundamental pension reform in wishing to opt out of the PAYG systems in favor of a mandatory partially funded system. Not too surprisingly, however, the people did not like the idea of bearing a transition burden. This is where this paper fills in: Even small gains in the efficiency of capital allocation in the wake of population aging and pension reform suffice to compensate for this transition burden, thereby fundamentally changing the political economy of pension reform. 


\section{References}

Aaron, H. (1966): The social insurance paradox. Canadian Journal of Economics and Political Science, 32, 371-374.

Alessie, R., and A. Kapteyn (2001): Household savings in the Netherlands. Research in Economics, 55, 61-82.

Arellano, M. and S. Bond (1991): Some tests of specification for panel data: Monte Carlo evidence and an application to employment equations. Review of Economic Studies, 58, 277 297.

Asher, M. G. (1998): Investment policies and performance of provident funds in Southeast Asia. Paper presented at Workshop on Pension System Reform, Governance, and Fund Management, January 1998.

Auerbach, A. J. and L. J. Kotlikoff (1987): Dynamic Fiscal Policy. Cambridge, MA: Cambridge University Press.

Babeau, A. and T. Sbano (2003): Household wealth in the national accounts of Europe, the United States and Japan. Working Paper 2003/2, Statistics Directorate, OECD, Paris.

Bank for International Settlements (1998): $68^{\text {th }}$ Annual Report. Basle.

Becht, M. and A. Röell (1999): Blockholdings in Europe: An international comparison. European Economic Review, 43, 1049-1056.

Becht, M. and E. Böhmer (2003): Voting control in German corporations. International Review of Law and Economics, 23, 1-29.

Beck, T. and R. Levine (2001): Stock markets, banks, and growth: Correlation or causality. Policy Research Paper No. 2670, The World Bank, Washington, D.C.

Beck, T. and R. Levine (2002): Industry growth and capital allocation: Does having a market or bank-based system matter? Journal of Financial Economics, 64, 147-180.

Beck, T., R. Levine, and N. Loayza (2000): Finance and the sources of growth. Journal of Financial Economics, 58, 261-300.

Black, B. S. (1998): Shareholder activism and corporate governance in the United States. In: P. Newman (ed.), New Palgrave Dictionary of Economics and Law. London: Macmillan.

Blanchet, D. (1999): Social Security and Retirement in France. In: Gruber, J., and D.A. Wise (eds.), International Social Security Comparisons. Chicago: University of Chicago Press.

Blommestein, H. (1998): Aging-induced capital flows to emerging markets do not solve OECD's basic pension problem. In: H. Blommestein and N. Funke (eds.), Institutional Investors in the New Financial Landscape. Paris: OECD.

Blommestein, H. (2001): Aging, financial reform, and financial market implications in the OECD area. Working Paper 9/01, Center for Research on Pension and Welfare Policies (CeRP).

Boeri, T., A. Börsch-Supan, and G. Tabellini (2001): Would you like to shrink the welfare state? The opinion of European citizens. Economic Policy, 32, 7-50. 
Boeri, T., A. Börsch-Supan, and G. Tabellini (2002): Pension reforms and the opinions of European citizens. American Economic Review, Papers \& Proceedings, 92:2, 396-401.

Boldrin, M., J. J. Dolado, J. F. Jimeno, and F. Peracchi (1999): The future of pensions in Europe. Economic Policy, 29, 289-320.

Börsch-Supan, A. (1998): Capital productivity and the nature of competition. Brookings Papers on Economic Activity: Microeconomics, 205-244.

Börsch-Supan, A. (2001): International comparison of household savings behavior: A study of life-cycle savings in seven countries. Research in Economics, 55, 1-14.

Börsch-Supan, A. (2002): A Blueprint for Germany's Pension Reform. Discussion Paper No. 022002, Mannheim Research Institute for the Economics of Aging (MEA), University of Mannheim.

Börsch-Supan, A., A. Ludwig, and J. Winter (2004): Aging, pension reform and capital flows: A multi-country simulation model. Mimeo, Mannheim Research Institute for the Economics of Aging (MEA), University of Mannheim.

Börsch-Supan, A., A. Reil-Held, R. Rodepeter, R. Schnabel, and J. Winter (2001): The German saving puzzle. Research in Economics, 55, 15-38.

Börsch-Supan, A., and R. Schnabel (1999): Social Security and Retirement in Germany. In: Gruber, J., and D. Wise (eds.): International Comparison of Social Security Systems. Chicago: The University of Chicago Press.

Börsch-Supan, A., and J. Winter (2001): Population aging, savings behavior and capital markets. Working Paper No. 8561, National Bureau of Economic Research (NBER).

Brugiavini, A. (1999): Social Security and Retirement in Italy. In: Gruber, J., and D. A. Wise (eds.), International Social Security Comparisons. Chicago: University of Chicago Press.

Brugiavini, A. and M. Padula (2001): Too much for retirement? Saving in Italy. Research in Economics, 55, 39-60.

Brunner, J. (1996): Transition from a pay-as-you-go to a fully funded pension system: The case of differing individuals and intragenerational fairness. Journal of Public Economics, 60, $131-146$.

Cable, J. (1985): Capital market and industrial performance: The role of West German banks. Economic Journal, 95, 118-132.

Carleton, W. T., J. M. Nelson, and M. S. Weisbach (1998): The influence of institutions on corporate governance through private negotiations: Evidence from TIAA-CREF. Journal of Finance, 53, 1335-1362.

Carlin, W., and C. Mayer (2003): Finance, investment, and growth. Journal of Financial Economics, 69, 191-226.

Chand, S. K. and A. Jaeger (1996): Aging populations and public pension schemes. IMF Occasional Papers, No. 147, International Monetary Fund, Washington D.C.

Davis, E. P. (2002): The European financial management industry. Forthcoming, Revue d'Economie Financière. 
Del Guercio, D. and J. Hawkins (1999): The motivation and impact of pension fund activism. Journal of Financial Economics, 52, 293-340.

Deutsches Aktieninstitut (2002): DIA Factbook. Frankfurt am Main: Deutsches Aktieninstitut.

Disney, R. (2000): Crises in public pension programs in OECD: What are the reform option? Economic Journal, 110, F1-F23.

Economic Policy Committee (2000): Progress report to the Ecofin Council on the impact of ageing populations on public pension systems, EPC/ECFIN/581/00, 6. November 2000, European Commission, Brussels.

Edwards, J. and K. Fischer (1994): Banks, Finance and Investment in Germany. Cambridge: Cambridge University Press.

Edwards, J. and M. Nibler (2000): Corporate governance in Germany: The role of banks and ownership structure. Economic Policy, 31, 239-267.

Elsas, R. and J. P. Krahnen (1998): Is relationship lending special? Evidence from credit-file data in Germany. Journal of Banking and Finance, 22, 1283-1316.

Faccio, M. and A. M. Lasfer (2000): Do occupational pension funds monitor companies in which they hold large stakes? Journal of Corporate Finance, 6, 71-110.

Fall, M., C. Loisy, and G. Talon (2001): An empirical analysis of household savings in France 1984-1998. Research in Economics, 55, 155-172.

Fenge, R. (1997): Effizienz der Alterssicherung. Frankfurt: Physica-Verlag.

Franks, J., C. Mayer, and L. Renneboog (2001): Who disciplines the management of poorly performing companies? Journal of Financial Intermediation, 10, 209- 248.

Götzfried, A. (1999): Statistik über Pensionsfonds. Luxemburg: Eurostat.

Gorton, G. and F. A. Schmid (2000): Universal banking and the performance of German firms. Journal of Financial Economic, 58, 29-80.

Grossman, S. J. and J. E. Stiglitz (1980): On the impossibility of informationally efficient markets. American Economic Review, 70, 393-408.

Grossman, S. J. and O. D. Hart (1980): Takeover bids, the free-rider problem, and the theory of the corporation. Bell Journal of Economics, 11, 42-64.

Hall, R. E. and C. I. Jones (1996): The productivity of nations. Working Paper No. 5812, National Bureau of Economic Research, Cambridge, MA.

Higgins, M. (1998): Demography, national savings, and international capital flows. International Economic Review, 39, 343-369.

Holmstrom, B. and J. Tirole (1993): Market liquidity and performance monitoring. Journal of Political Economy, 101, 678-709.

Januszewski, S. I., J. Köke, and J. K. Winter (2002): Product market competition, corporate governance, and firm performance: An empirical analysis for Germany. Research in Economics, 56, 299-332. 
Jappelli, T. and F. Modigliani (1998), The age-saving profile and the life-cycle hypothesis, CSEF Working Paper No. 4, University of Salerno.

Jensen, M. C. and K. J. Murphy (1990): Performance pay and top-management incentives. Journal of Political Economy, 98, 225-264.

Jensen, M. C. and W. R. Meckling (1976): Theory of the firm: Managerial behavior, agency costs, and ownership structure. Journal of Financial Economics, 3, 305-360.

Jensen, M. C. (1986): Agency costs of free cash flow, corporate finance, and takeovers. American Economic Review, 76, 323-329.

Kim, J.-I. and L. J. Lau (1994): The sources of economic growth of the East Asian newly industrialized countries. Journal of the Japanese and International Economies, 8, 235-271.

Köke, J. and L. Renneboog (2002): Does good corporate governance lead to stronger productivity growth? Evidence from market-oriented and blockholder-based governance regimes. Discussion Paper No. 2002-89, CentER, Tilburg University.

Köke, J. (2002a): Corporate governance in Germany: An empirical investigation. Heidelberg: Physica.

Köke, J. (2002b): The market for corporate control in a bank-based economy: A governance device? Journal of Corporate Finance, forthcoming.

Lehmann, E. and J. Weigand (2000): Does the governed corporation perform better? Governance structures and corporate performance in Germany. European Finance Review, 4, 157195.

Levine, R. (1997): Financial development and economic growth: Views and agenda. Journal of Economic Literature, 35, 688-726.

Levine, R. and S. Zervos (1998): Stock markets, banks, and economic growth. American Economic Review, 88:3, 537-58.

Levine, R., N. Loayza, and T. Beck (2000): Financial intermediation and growth: Causality and causes. Journal of Monetary Economics, 46, 31-77.

Loayza, N., K. Schmidt-Hebbel, and L. Serven (2000): What drives saving across the world? Review of Economics and Statistics, 82, 165-181.

Lührmann, M. (2003): Demographic change, foresight, and international capital flows. Discussion Paper No. 38-2003, Mannheim Research Institute for the Economics of Aging (MEA), University of Mannheim.

McKinsey Global Institute (1996): Capital Productivity. Washington, D.C.: McKinsey Global Institute.

Miles, D. and A. Timmermann (1999): Risk sharing and transition costs in the reform of pension systems in Europe. Economic Policy, 29, 253-286.

Mueller, D. C. and B. B. Yurtoglu (2000): Country legal environments and corporate investment performance. German Economic Review, 1, 187-220.

Nesbitt, S. L. (1994): Long-term rewards from shareholder activism: A study of the CalPERS effect. Journal of Applied Corporate Governance, 6, 75-80. 
Neusser, K. and M. Kugler (1998): Manufacturing growth and financial development: Evidence from OECD countries. Review of Economics and Statistics, 80, 638-646.

Nickell, S. and D. Nicolitsas (1999): How does financial pressure affect firms? European Economic Review, 43, 1435-1456.

Nickell, S., D. Nicolitsas, and N. Dryden (1997): What makes firms perform well? European Economic Review, 41, 783-796.

Organization for Economic Cooperation and Development (1988): Aging Populations: The Social Policy Implications, Paris: OECD.

Organization for Economic Cooperation and Development (2000): Institutional Investors - Statistical Yearbook. Paris: OECD.

Organization for Economic Cooperation and Development (2001): Financial Market Trends, No. 80. Paris: OECD.

Pound, J. (1988): Proxy contests and the efficiency of shareholder oversight. Journal of Financial Economics, 20, 237-265.

Rajan, R. G., and L. Zingales (1998): Financial dependence and growth. American Economic Review, 88:3, 559-88.

Rajan, R. G. and L. Zingales (2001): Financial systems, industrial structure, and growth. Oxford Review of Economic Policy, 17:4, 467-482.

Reisen, H. (2000): Pensions, Savings and Capital Flows: From Aging to Emerging Markets. Edward Elgar.

Renneboog, L. (2000): Ownership, managerial control, and the governance of companies listed on the Brussels stock exchange. Journal of Banking and Finance, 24, 1959-1995.

Rosevaere, D., W. Leibfritz, D. Fore, and E. Wurzel (1996): Aging Populations, Pension Systems and Government Budgets: Simulation for 20 OECD Countries, Paris: OECD.

Scatinga, M. (2001) : Institutional investors, corporate governance, and pension funds. Working Paper 13/01, Center for Research on Pension and Welfare Policies (CeRP).

Shleifer, A. and R. W. Vishny (1986): Large shareholders and corporate control. Journal of Political Economy, 94, 461-488.

Sinn, H. W. (2000): Pension reform and demographic crisis: Why a funded system is needed and why it is not needed. International Tax and Public Finance, 7, 389-410.

Smith, M. P. (1996): Shareholder activism by institutional investors: Evidence from CalPERS. Journal of Finance, 51, 227-252.

United Nations Population Division (2002): World Population Prospects: The 2000 Revision. New York: United Nations.

Wenger, E. and C. Kaserer (1998): The German system of corporate governance - A model which should not be imitated. In: S. Black and M. Moersch (eds.), Competition and Convergence in Financial Markets: The German and Anglo-American Models. Amsterdam: Elsevier, 41-78.

World Bank (1994): Averting the Old Age Crisis. Oxford: Oxford University Press. 
Wurgler, J. (2000): Financial markets and the allocation of capital. Journal of Financial Economics, 58, 187-214.

Young, A. (1994): Lessons from the East Asian NICs: A contrarian view. European Economic Review, 38. 
Table 1: The future of pay-as-you-go pension systems

\begin{tabular}{lccc}
\hline & $\mathbf{1 9 9 5}$ & $\mathbf{2 0 1 0}$ & $\mathbf{2 0 3 0}$ \\
\hline France & & & \\
Pension expenditures (\%GDP) & 12.5 & 12.6 & 19.4 \\
Equilibrium contribution rate (\%wage bill) & 24.3 & 24.4 & 37.7 \\
Fiscal deficit (\%wage bill) & 0.5 & 0.6 & 100.5 \\
Germany & & 11.0 & 18.4 \\
Pension expenditures (\%GDP) & 10.0 & 24.7 & 41.1 \\
Equilibrium contribution rate (\%wage bill) & 22.6 & 8.8 & 115.6 \\
Fiscal deficit (\%wage bill) & $(1.1)^{\mathrm{a}}$ & 15.2 & 23.3 \\
Italy & & 16.0 & 61.9 \\
Pension expenditures (\%GDP) & 42.6 & 40.4 & 186.8 \\
Equilibrium contribution rate (\%wage bill) & 0 & 29.9 \\
Fiscal deficit (\%wage bill) & & & \\
\hline
\end{tabular}

Notes: The equilibrium contribution rate is the percent of the wage bill required if the increase in pension expenditures is financed by contributions only. The fiscal deficit is the percent of the wage bill arising if the increase in pension expenditures is financed by debt only. a) Surplus.

Source: Chand and Jaeger (1996).

Table 2: Capital markets in countries with pay-as-you-go and funded pensions systems

\begin{tabular}{|c|c|c|c|c|c|c|c|}
\hline & \multirow[b]{2}{*}{ Year } & \multicolumn{3}{|c|}{ Pay-as-you-go systems } & \multicolumn{3}{|c|}{ Partially funded systems } \\
\hline & & France & Germany & Italy & Netherlands & $\mathbf{U K}$ & $\mathbf{U S}$ \\
\hline \multirow{3}{*}{$\begin{array}{l}\text { Stock market capitalization } \\
(\% \text { of GDP })^{a}\end{array}$} & 1995 & 32.6 & 23.9 & 19.3 & 72.1 & 121.6 & 95.2 \\
\hline & 1998 & 68.1 & 50.9 & 47.5 & 153.5 & 168.2 & 144.9 \\
\hline & 2000 & 111.8 & 67.6 & 72.3 & 174.3 & 183.8 & 153.3 \\
\hline \multirow{2}{*}{$\begin{array}{l}\text { Assets held by institutional } \\
\text { investors }\left(\% \text { of GDP) }{ }^{b}\right.\end{array}$} & 1995 & 77.7 & 45.3 & 32.0 & 154.5 & 164.0 & 151.9 \\
\hline & 1998 & 107.3 & 66.1 & 79.6 & 193.2 & 203.6 & 192 \\
\hline $\begin{array}{l}\text { Assets held by pension funds } \\
(\% \text { of total assets of institutional } \\
\text { investors })^{c}\end{array}$ & 1998 & . & 5 & 5 & 58 & 38 & 37 \\
\hline \multirow{2}{*}{$\begin{array}{l}\text { Assets held by pension funds } \\
\text { (billion USD) }^{\mathrm{a}}\end{array}$} & 1995 & . & 65.3 & 39.0 & 352.1 & 759.7 & $4,259.5$ \\
\hline & 1998 & . & 69.5 & 37.4 & 323.0 & $1,136.5$ & $7,161.6$ \\
\hline \multirow{2}{*}{$\begin{array}{l}\text { Pension fund investment } \\
(\% \text { of household wealth }){ }^{d}\end{array}$} & 1995 & 1.8 & 5.6 & 0.8 & 35.5 & 22.3 & 23.4 \\
\hline & 2000 & 1.5 & 5.2 & 1.2 & 37.7 & 22.1 & 23.8 \\
\hline
\end{tabular}

Sources: a) Deutsches Aktieninstitut (2002); b) OECD (2001); c) OECD (2000); d) Babeau and Sbano (2003). 
Table 3: Capital performance relative to the United States

\begin{tabular}{lccc}
\hline & France & Germany & Italy \\
\hline Aggregate return on investment $^{\text {a }}$ & 77 & 61 & 50 \\
Mean return on investment (firm sample) $^{\mathrm{b}}$ & 73 & 72 & 57 \\
Market sector capital productivity $^{\mathrm{c}}$ & 72 & 67 & $\cdot$ \\
Total factor productivity $^{\mathrm{d}}$ & 82 & 81 & 84 \\
\hline
\end{tabular}

Note: All figures are expressed as a percentage of the corresponding U.S. value.

Sources: a) Mueller and Yurtoglu (2000), Table 2. b) ditto, Table 4. c) Börsch-Supan (1998), Table 3.

d) Hall and Jones (1996), Table 9.

Table 4: Corporate governance variables

\begin{tabular}{lcc}
\hline & Germany & UK \\
\hline Strong owner (CONTROL) & Mean ownership concentration (median in parentheses) \\
Ownership concentration (BLOCK) & $79.6 \%(100 \%)$ & $83.0 \%(100.0 \%)$ \\
Ownership concentration (HERF) & $66.9 \%(81.0 \%)$ & $20.8 \%(15.6 \%)$ \\
\hline & Type of ultimate owner & Type of largest shareholder \\
\hline Individuals & $35.6 \%$ & $29.4 \%$ \\
thereof: Insider & $25.0 \%$ & $26.9 \%$ \\
Financial firm & $7.8 \%$ & $45.3 \%$ \\
thereof: Bank & $5.4 \%$ & $3.7 \%$ \\
\multicolumn{1}{c}{ Insurance company } & $2.3 \%$ & $2.0 \%$ \\
Mutual fund & $0.0 \%$ & $39.2 \%$ \\
Non-financial firm & $41.4 \%$ & $8.3 \%$ \\
Government & $4.8 \%$ & $0.0 \%$ \\
Dispersed & $10.4 \%$ & $17.0 \%$ \\
\hline Bank debt ratio (BANK) & \multicolumn{1}{c}{ Measure of capital structure } \\
Borrowing ratio (BORROW) & $26.1 \%$ & $15.1 \%$ \\
\hline Number of observations & & 2280 \\
\hline
\end{tabular}

Source: Authors' calculation based on German and UK firm panel. 
Table 5: Effects of corporate governance and product market competition on productivity growth

\begin{tabular}{|c|c|c|c|c|c|c|c|c|}
\hline \multirow{3}{*}{ Independent variables } & \multicolumn{8}{|c|}{ Dependent variable: output growth $\left(\Delta \mathrm{y}_{\mathrm{it}}\right)$} \\
\hline & Model & Model & & & $\operatorname{Model}\left(1_{\mathrm{UK}}\right)$ & $\operatorname{Model}\left(2_{\mathrm{UK}}\right)$ & & \\
\hline & & & $\begin{array}{l}\text { Interaction } \\
\text { with } \\
\text { RENT }_{\mathrm{t}-1}\end{array}$ & $\begin{array}{l}\text { Interac- } \\
\text { tion with } \\
\text { LOSS }_{\mathrm{t}-1}\end{array}$ & & & $\begin{array}{l}\text { Interac- } \\
\text { tion with } \\
\text { RENT }_{\mathrm{t}-1}\end{array}$ & $\begin{array}{l}\text { Interac- } \\
\text { tion with } \\
\text { LOSS }_{\mathrm{t}-1}\end{array}$ \\
\hline Lagged output growth $\left(\Delta \mathrm{y}_{\mathrm{t}-1}\right)$ & $-0.116(0.345)$ & $-0.144(0.200)$ & & & $0.317 * *(0.050)$ & $0.286 *(0.055)$ & & \\
\hline Capital growth $\left(\Delta \mathrm{k}_{\mathrm{t}-1}\right)$ & $0.297(0.271)$ & $0.247(0.330)$ & & & $0.145(0.122)$ & $0.112(0.181)$ & & \\
\hline Labor growth $\left(\Delta \mathrm{l}_{\mathrm{t}-1}\right)$ & $0.778 * * *(0.000)$ & $0.788 * * *(0.000)$ & & & $\begin{array}{l}0.662 * * * \\
(0.000)\end{array}$ & $\begin{array}{l}0.741 * * * \\
(0.000)\end{array}$ & & \\
\hline Rent $\left(\operatorname{RENT}_{\mathrm{t}-1}\right)$ & $-0.638 * *(0.031)$ & $-0.232(0.510)$ & & & $-0.039(0.593)$ & $-0.252 *(0.091)$ & & \\
\hline Bank debt $\left(\right.$ BANK $\left._{t-1}\right)$ & $0.238 * *(0.012)$ & $-0.415(0.131)$ & $\begin{array}{l}1.563 * \\
(0.052)\end{array}$ & $\begin{array}{l}5.221 * * \\
(0.030)\end{array}$ & & & & \\
\hline Borrowing ratio $\left(\mathrm{BORROW} \mathrm{W}_{\mathrm{t}-1}\right)$ & & & & & $-0.043(0.239)$ & $0.011(0.837)$ & $\begin{array}{l}0.060 \\
(0.831)\end{array}$ & $\begin{array}{l}0.031 \\
(0.710)\end{array}$ \\
\hline Strong owner $\left(\right.$ CONTROL $\left._{t-1}\right)$ & $0.002(0.928)$ & $0.171 *(0.084)$ & $\begin{array}{l}-0.471 * \\
(0.083)\end{array}$ & $\begin{array}{l}-0.193 \\
(0.720)\end{array}$ & $-0.003(0.900)$ & $\begin{array}{l}-0.079 * * \\
(0.039)\end{array}$ & $\begin{array}{l}0.369 * * \\
(0.030)\end{array}$ & $\begin{array}{l}0.198 * * * \\
(0.006)\end{array}$ \\
\hline Business cycle $\left(\mathrm{CYCLE}_{\mathrm{t}}\right)$ & $0.010(0.598)$ & $0.011(0.562)$ & & & $-0.005(0.134)$ & $-0.006(0.104)$ & & \\
\hline Ln (total assets) $\left(\mathrm{ASSET}_{\mathrm{t}-1}\right)$ & $0.010(0.485)$ & $0.006(0.696)$ & & & $-0.005(0.222)$ & $-0.002(0.510)$ & & \\
\hline Number of observations & 3853 & 3853 & & & 832 & 832 & & \\
\hline Instrument validity (Sargan test) & $\mathrm{p}=0.4171$ & $\mathrm{p}=0.2629$ & & & $\mathrm{p}=0.3868$ & $\mathrm{p}=0.5779$ & & \\
\hline Second-order corr. of resid. & $\mathrm{p}=0.6753$ & $\mathrm{p}=0.7173$ & & & $\mathrm{p}=0.1160$ & $\mathrm{p}=0.1094$ & & \\
\hline Const. returns to scale & $\mathrm{p}=0.5651$ & $\mathrm{p}=0.5917$ & & & $\mathrm{p}=0.1086$ & $\mathrm{p}=0.1118$ & & \\
\hline
\end{tabular}

Notes: GMM regression results relating corporate governance and product market competition to productivity growth. The sample includes only manufacturing and construction firms. Estimates are obtained using the Arellano and Bond (1991) method. All regressions include time and two-digit industry dummies. Instruments are $\mathrm{y}_{\mathrm{it}-\mathrm{j}}$ and the second lags of ASSET and RENT. The $p$-values (reported in parentheses) are based on robust standard errors, which are calculated using the White/Huber sandwich estimator for the variance-covariance matrix. *, **, *** indicates significance at the $0.10,0.05$, and 0.01 levels, respectively. Source: Authors' calculation. 
Table 6: Effects of corporate governance and product market competition on productivity growth, ownership categories

\begin{tabular}{|c|c|c|c|c|c|c|}
\hline \multirow{3}{*}{ Independent variables } & \multicolumn{6}{|c|}{ Dependent variable: output growth $\left(\Delta \mathrm{y}_{\mathrm{it}}\right)$} \\
\hline & Model ( $\left.3_{\text {GERMANY }}\right)$ & & & Model ( $\left.3_{\mathrm{UK}}\right)$ & & \\
\hline & & $\begin{array}{l}\text { Interaction with } \\
\mathrm{RENT}_{\mathrm{t}-1}\end{array}$ & $\begin{array}{l}\text { Interaction with } \\
\text { LOSS }_{\mathrm{t}-1}\end{array}$ & & $\begin{array}{l}\text { Interaction with } \\
\text { RENT }_{\mathrm{t}-1}\end{array}$ & $\begin{array}{l}\text { Interaction } \\
\text { LOSS }_{\mathrm{t}-1}\end{array}$ \\
\hline Lagged output growth $\left(\Delta \mathrm{y}_{\mathrm{t}-1}\right)$ & $-0.160(0.136)$ & & & $0.300 * *(0.042)$ & & \\
\hline Capital growth $\left(\Delta \mathrm{k}_{\mathrm{t}-1}\right)$ & $0.273(0.264)$ & & & $0.087(0.262)$ & & \\
\hline Labor growth $\left(\Delta \mathrm{l}_{\mathrm{t}-1}\right)$ & $0.768 * * *(0.000)$ & & & $0.745 * * *(0.000)$ & & \\
\hline $\operatorname{Rent}\left(\mathrm{RENT}_{\mathrm{t}-1}\right)$ & $0.194(0.505)$ & & & $-0.262 *(0.085)$ & & \\
\hline Bank debt $\left(\mathrm{BANK}_{\mathrm{t}-1}\right)$ & $-0.129(0.703)$ & $0.569(0.582)$ & $4.443 * *(0.039)$ & & & \\
\hline Borrowing ratio $\left(\mathrm{BORROW} \mathrm{W}_{\mathrm{t}-1}\right)$ & & & & $0.038(0.486)$ & $-0.170(0.577)$ & $0.055(0.554)$ \\
\hline Owner $\left(\right.$ TYPE $_{\mathrm{t}-1}=$ private $)$ & $0.040(0.693)$ & $-0.121(0.666)$ & $0.598(0.479)$ & & & \\
\hline Owner $\left(\right.$ TYPE $_{t-1}=$ private, insider $)$ & & & & $-0.158 * * *(0.004)$ & $0.686 * * *(0.005)$ & $0.259 * *(0.017)$ \\
\hline Owner $\left(\mathrm{TYPE}_{\mathrm{t}-1}=\right.$ private, outsider $)$ & & & & $-0.040(0.291)$ & $0.258(0.134)$ & $0.319 * *(0.011)$ \\
\hline Owner $\left(\right.$ TYPE $_{t-1}=$ bank $)$ & $0.607 * * *(0.004)$ & $-2.388 * * *(0.006)$ & $-1.214(0.313)$ & $-0.063 *(0.079)$ & $0.400 * *(0.023)$ & $0.402 * *(0.042)$ \\
\hline Owner $\left(\right.$ TYPE $_{t-1}=$ insurer $)$ & $0.373 * * *(0.008)$ & $-1.089 * *(0.022)$ & $0.220(0.369)$ & $-0.143(0.174)$ & $0.442(0.285)$ & $0.172(0.137)$ \\
\hline Owner $\left(\mathrm{TYPE}_{\mathrm{t}-1}=\right.$ fund $)$ & $2.019(0.354)$ & $-5.391(0.455)$ & n.a. & $-0.041(0.308)$ & $0.232(0.191)$ & $0.151 * *(0.044)$ \\
\hline Owner $\left(\mathrm{TYPE}_{\mathrm{t}-1}=\right.$ non-fin. firm $)$ & $0.159(0.155)$ & $-0.380(0.234)$ & $-0.119(0.870)$ & $-0.042(0.435)$ & $0.136(0.579)$ & $0.175(0.116)$ \\
\hline Owner $\left(\right.$ TYPE $_{t-1}=$ government $)$ & $0.440 *(0.066)$ & $-1.621 * *(0.017)$ & $0.193(0.911)$ & & & \\
\hline Business cycle $\left(\mathrm{CYCLE}_{\mathrm{t}}\right)$ & $0.011(0.534)$ & & & $-0.006(0.107)$ & & \\
\hline Ln (total assets) (ASSET $\left.\mathrm{AS}_{\mathrm{t}-1}\right)$ & $0.001(0.918)$ & & & $-0.004(0.249)$ & & \\
\hline Number of observations & 3853 & & & 832 & & \\
\hline Instrument validity (Sargan test) & $\mathrm{p}=0.2707$ & & & $\mathrm{p}=0.6778$ & & \\
\hline Second-order corr. of resid. & $\mathrm{p}=0.8434$ & & & $\mathrm{p}=0.2273$ & & \\
\hline Const. returns to scale & $\mathrm{p}=0.5354$ & & & $\mathrm{p}=0.1046$ & & \\
\hline
\end{tabular}

Notes and source: See Table 5. 
Figure 1: Saving rates in France, Germany and Italy under alternative capital mobility scenarios

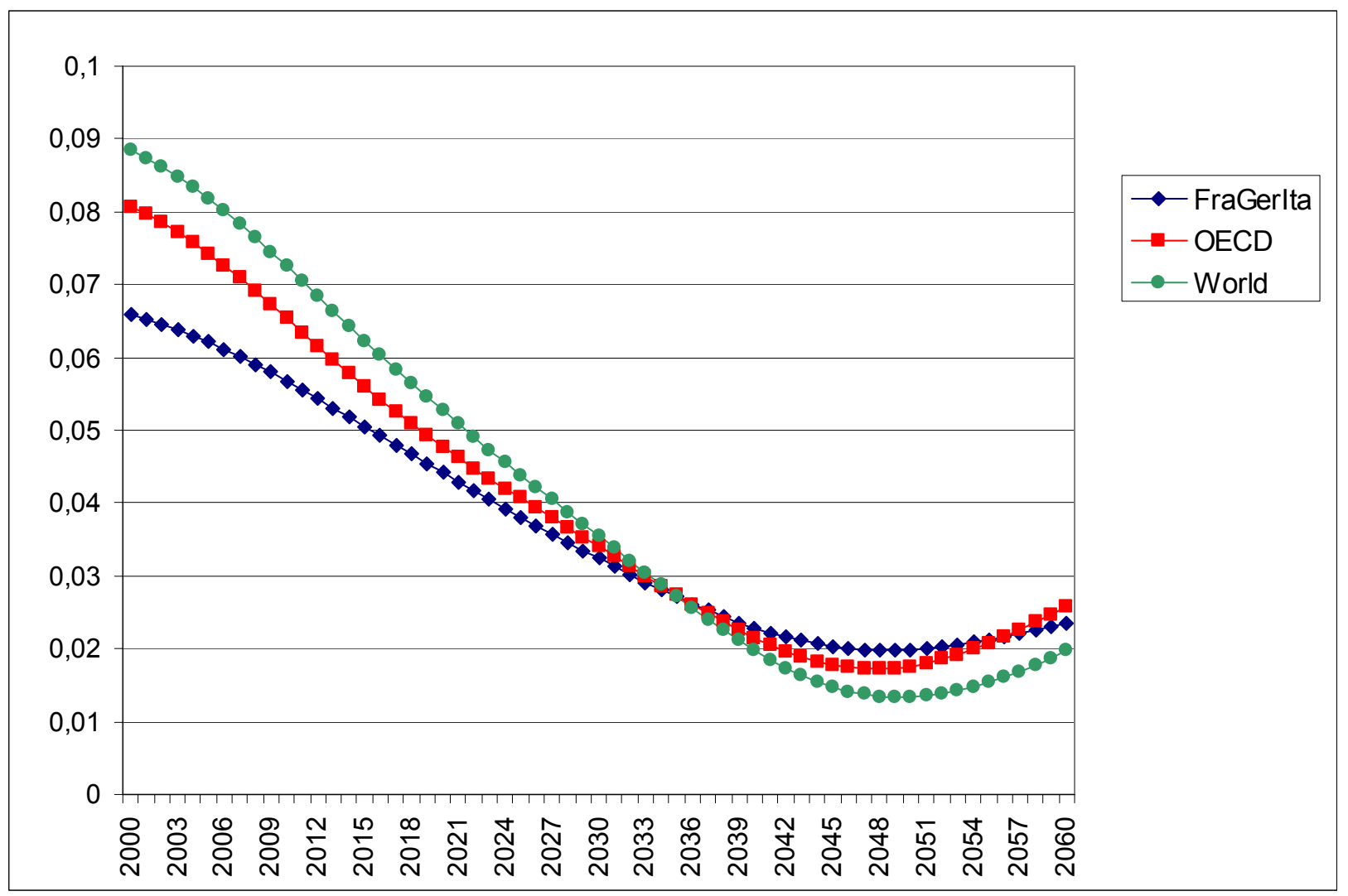

Notes: These figures show the projected aggregate saving rate of households living in France, Germany and Italy under the current pension scenario. The capital mobility scenarios are as follows. Scenario FraGerIta: perfect capital mobility only within the three countries. Scenario OECD: perfect capital mobility with the OECD. Scenario WORLD: perfect capital mobility across all world regions.

Source: Authors' calculations based on Börsch-Supan, Ludwig, and Winter (2004). 
Figure 2: Reform-induced savings in France, Germany and Italy under alternative capital mobility scenarios

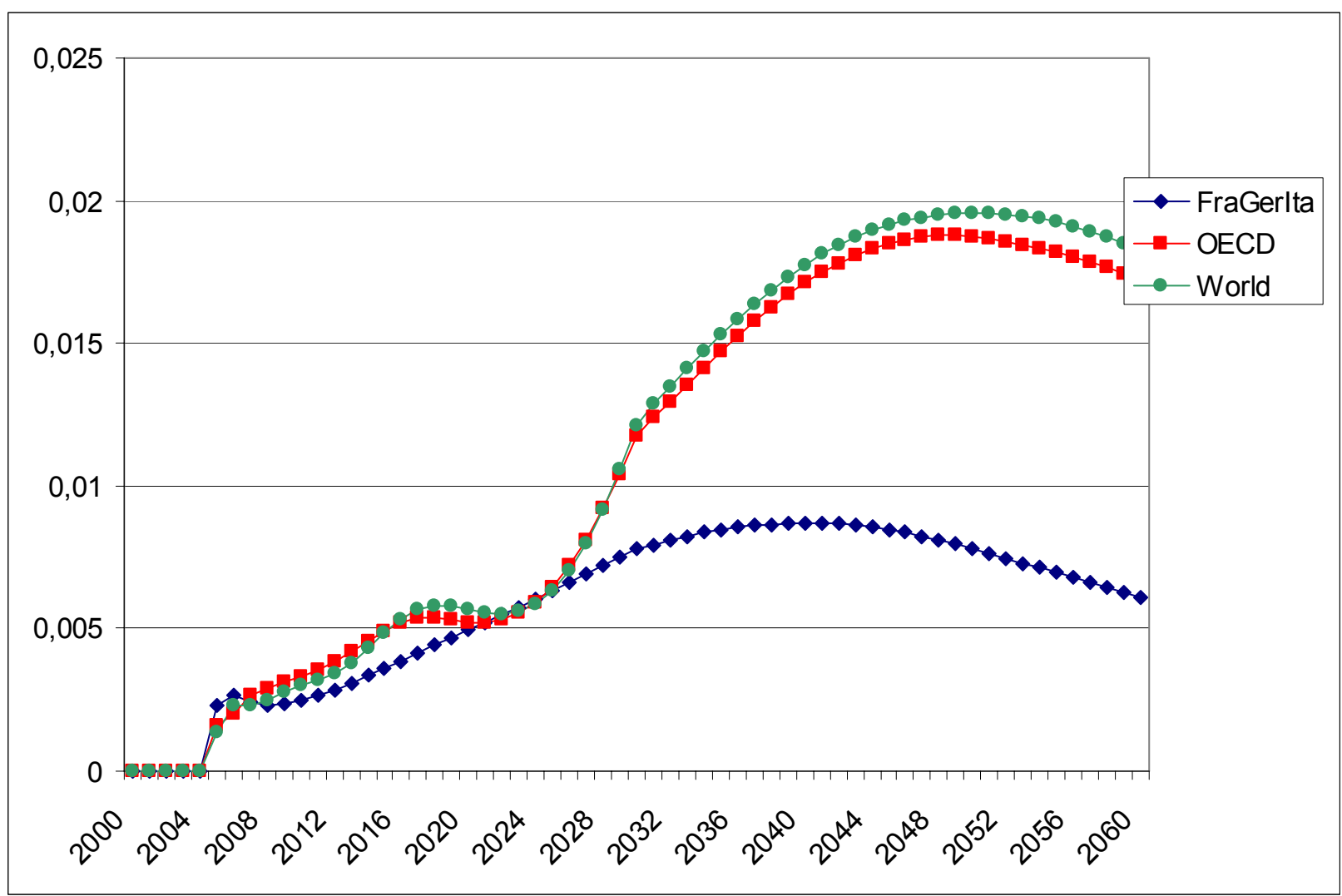

Notes: These figures show the increase of the aggregate saving rate of households living in France, Germany and Italy when a fundamental pension reform is implemented in these three countries. The capital mobility scenarios are as follows. Scenario FraGerIta: perfect capital mobility only within the three countries. Scenario OECD: perfect capital mobility with the OECD. Scenario WORLD: perfect capital mobility across all world regions.

Source: Authors' calculations based on Börsch-Supan, Ludwig, and Winter (2004). 
Figure 3: Share of retirement saving in France, Germany and Italy under alternative capital mobility scenarios

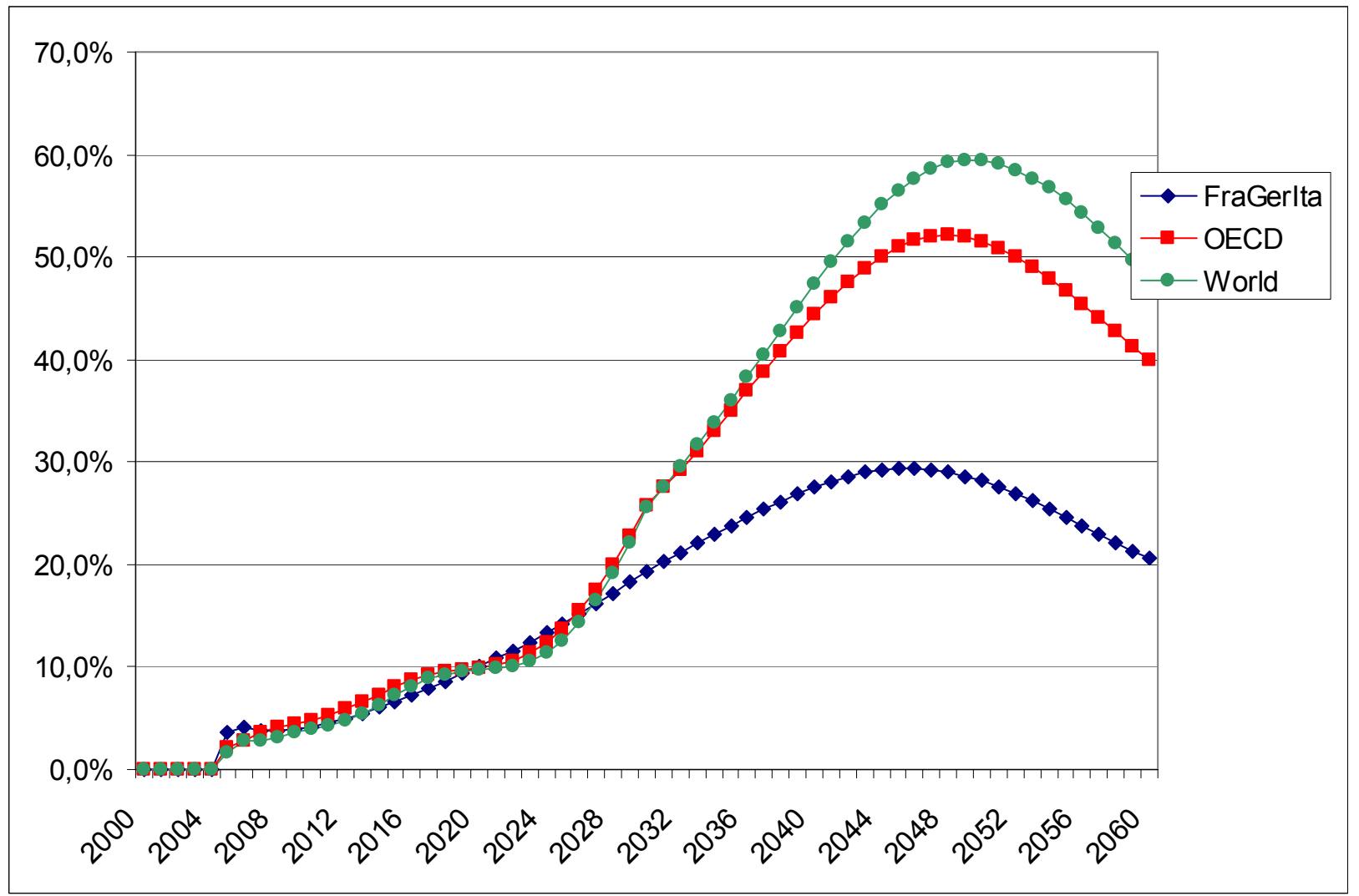

Notes: These figures show the share of retirement saving in total saving in France, Germany and Italy when a fundamental pension reform is implemented in these three countries. The capital mobility scenarios are as follows. Scenario FraGerIta: perfect capital mobility only within the three countries. Scenario OECD: perfect capital mobility with the OECD. Scenario WORLD: perfect capital mobility across all world regions.

Source: Authors' calculations based on Börsch-Supan, Ludwig, and Winter (2004). 
Figure 4: Cohort-corrected savings rates by age, Germany

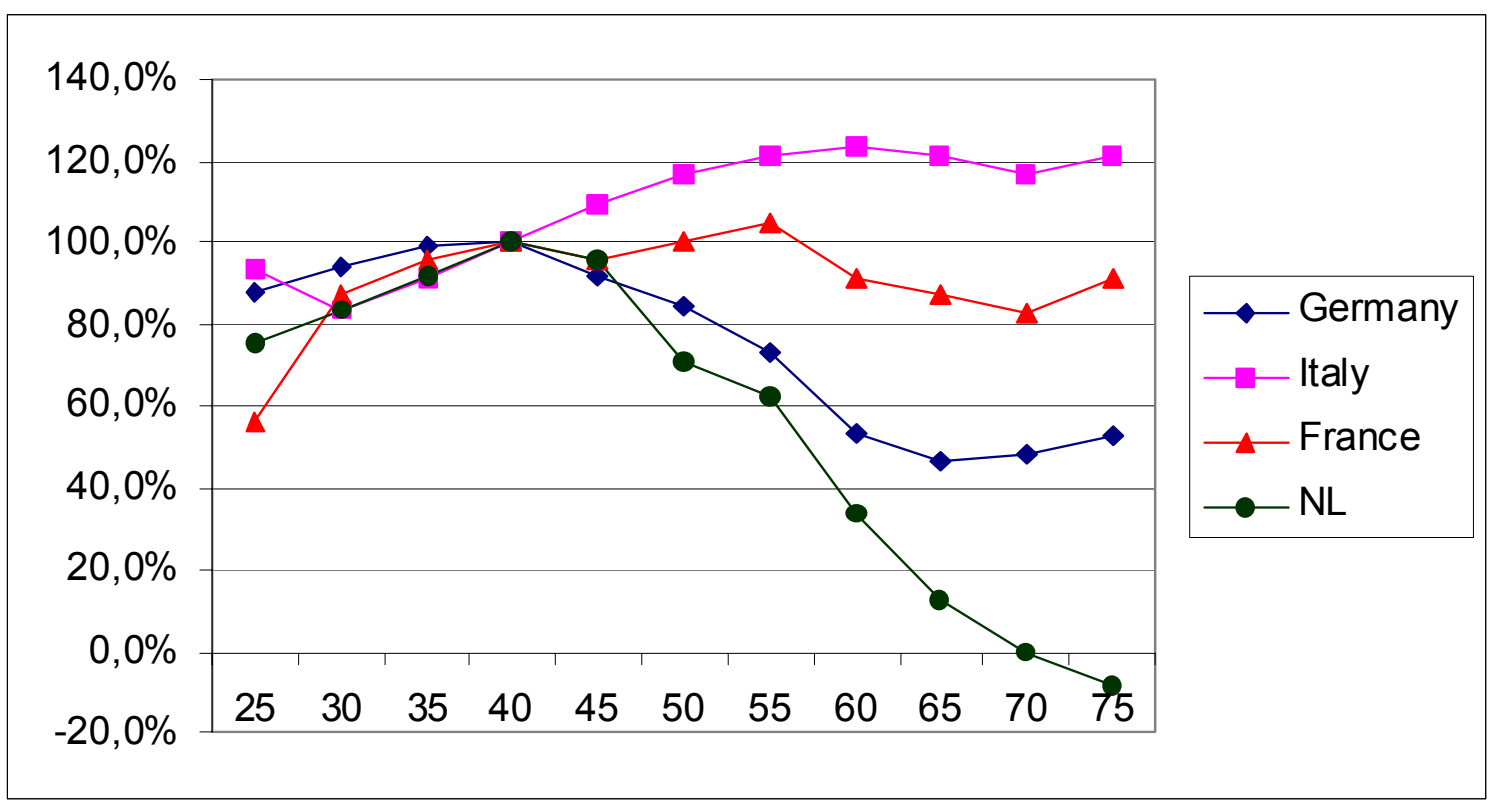

Sources: Authors' calculations based on the International Savings Comparisons Project. France: Fall, Loisy, and Talon (2001); Germany: Börsch-Supan, Reil-Held, Rodepeter, Schnabel, and Winter (2001); Italy: Brugiavini and Padula (2001); Netherlands: Alessie and Kapteyn (2001). 
Figure 5: Projected welfare effects of improved productivity growth rates in Germany

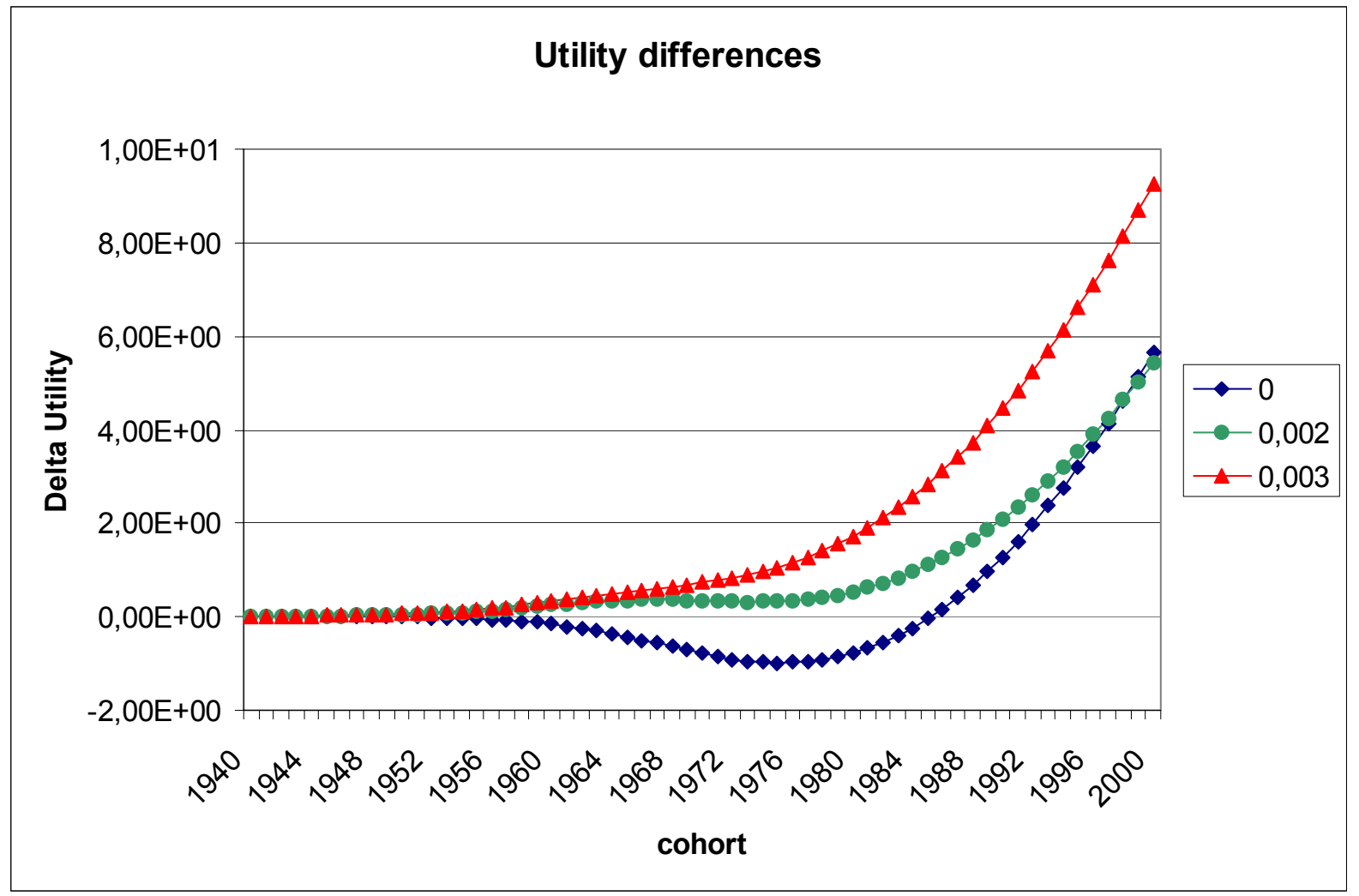

Notes: This figure shows, by birth cohort, the change in total discounted life-time utility induced by a fundamental pension reform. The for lines correspond to hypothetical transient improvements in the growth rate of total factor productivity.

Sources: Authors' calculations based on Börsch-Supan, Ludwig and Winter (2004). 


\section{Discussion Paper Series}

Mannheim Research Institute for the Economics of Aging Universität Mannheim

To order copies, please direct your request to the author of the title in question.

\begin{tabular}{|c|c|c|c|}
\hline Nr. & Autoren & Titel & Jahr \\
\hline $40-03$ & Christoph Buchheim & $\begin{array}{l}\text { Das Zusammenspiel von Wirtschaft, Bevölkerung } \\
\text { und Wohlstand aus historischer Sicht }\end{array}$ & 03 \\
\hline $41-03$ & Oliver Lipps & $\begin{array}{l}\text { Stochastische Bevölkerungsprognose für West- } \\
\text { und Ostdeutschland }\end{array}$ & 03 \\
\hline $42-03$ & Axel Börsch-Supan & $\begin{array}{l}\text { What are NDC Pension Systems? What Do They } \\
\text { Bring to Reform Satrategies? }\end{array}$ & 03 \\
\hline $43-04$ & Matthias Weiss & $\begin{array}{l}\text { Employment of Skill Biased Technological } \\
\text { Change when Benefits are Linked to Per-Capita } \\
\text { Income }\end{array}$ & 04 \\
\hline $44-04$ & $\begin{array}{l}\text { Alexander Ludwig } \\
\text { and Torsten Sløk }\end{array}$ & $\begin{array}{l}\text { The relationship between stock prices, house } \\
\text { prices and consumption in OECD countries }\end{array}$ & 04 \\
\hline $45-04$ & Matthias Weiss & $\begin{array}{l}\text { Skill-Biased Technological Change: Is there Hope } \\
\text { for the Unskilled? }\end{array}$ & 04 \\
\hline $46-04$ & $\begin{array}{l}\text { Hans-Martin von } \\
\text { Gaudecker }\end{array}$ & $\begin{array}{l}\text { Regionale Mortalitätsunterschiede in Baden- } \\
\text { Württemberg }\end{array}$ & 04 \\
\hline $47-04$ & Karsten Hank & $\begin{array}{l}\text { Effects of Early Life Family on Women's Late Life } \\
\text { Labour Market Behaviour: An Analysis of the } \\
\text { Relationship between Childbearing and } \\
\text { Retirement in Western Germany }\end{array}$ & 04 \\
\hline $48-04$ & $\begin{array}{l}\text { Christina Benita } \\
\text { Wilke }\end{array}$ & $\begin{array}{l}\text { Ein Simulationsmodell des Rentenversiche- } \\
\text { rungssystems: Konzeption und ausgewählte } \\
\text { Anwendungen von MEA-PENSIM }\end{array}$ & 04 \\
\hline $49-04$ & $\begin{array}{l}\text { Axel Börsch-Supan, } \\
\text { Alexander Ludwig } \\
\text { und Anette Reil-Held }\end{array}$ & $\begin{array}{l}\text { Hochrechnungsmethoden und Szenarien für } \\
\text { gesetzliche und private Renteninformationen }\end{array}$ & 04 \\
\hline $50-04$ & Axel Börsch-Supan & $\begin{array}{l}\text { From Public Pensions to Private Savings: The } \\
\text { Current Pension Reform Process in Europe }\end{array}$ & 04 \\
\hline $51-04$ & Axel Börsch-Supan & $\begin{array}{l}\text { Gesamtwirtschaftliche Folgen des } \\
\text { demographischen Wandels }\end{array}$ & 04 \\
\hline $52-04$ & Axel Börsch-Supan & $\begin{array}{l}\text { Mind the Gap: The Effectiveness of Incentives to } \\
\text { Boost Retirement Saving in Europe }\end{array}$ & 04 \\
\hline $53-04$ & $\begin{array}{l}\text { Axel Börsch-Supan, } \\
\text { F. Jens Köke and } \\
\text { Joachim K. Winter }\end{array}$ & $\begin{array}{l}\text { Pension reform, savings behavior and capital } \\
\text { market performance }\end{array}$ & 04 \\
\hline
\end{tabular}

